\title{
Persistent reaction in paucibacillary leprosy: case reports
}

\author{
UMA SAXENA*, V RAMESH, R S MISRA \& \\ ASHOK MUKHERJEE† \\ Department of Dermatology and Leprology and the †Institute of \\ Pathology (ICMR), New Delhi
}

\author{
Accepted for publication 9 November 1990
}

\begin{abstract}
Summary Three patients of histopathologically confirmed borderline-tuberculoid leprosy showing no acid-fast bacilli and with lesions confined to the face, 2 on the cheek and 1 on the forehead, were given multidrug therapy as recommended by the WHO for paucibacillary cases. Within 3 months the lesions showed signs of upgrading (or reversal) reaction which was substantiated by histopathology. In 1 patient the facial nerve was affected leading to facial palsy. The lymphocyte transformation test did not show a significant rise. All 3 patients were given oral prednisolone for periods varying between 5 and 7 months, but the response was poor except in 1 patient in whom the facial palsy responded favourably. Injections of sodium antimony gluconate tried in 1 patient af ter stoppage of steroids did not control the reaction. After 18 months of regular follow-up during therapy, the cutaneous reaction in the patient with facial nerve involvement subsided leaving significant atrophy. However, in the other 2 patients the skin lesion persisted with clinical and histopathological evidence of upgrading reaction. The reasons for the unnatural persistence of reaction in these patients is not clear.
\end{abstract}

\section{Introduction}

Reactions are an important clinical component of leprosy resulting from immunological changes in the patient. Alteration in cell-mediated immunity results in upgrading or downgrading reactions in borderline leprosy and antigen-antibody complexes are involved in reactions occurring in lepromatous leprosy. Being acute exacerbations these reactions can lead to severe tissue damage which in the nerves may lead to paralysis. Fortunately with the administration of anti-inflammatory drugs and corticosteroids reactions can be brought under control. This report describes 3 patients in whom the reaction persisted unusually up to 18 months and more despite proper therapy.

* Correspondence: DII/146, West Kidwai Nagar, New Delhi 110 023, India. 


\section{Case 1}

A 48-year-old woman came to the clinic with a localized skin lesion on the forehead of 6 months' duration. On examination a well-defined, raised, erythematous, indurated, hypoaesthetic plaque on the forehead above the left eye extending to the root of the nose was seen. Hairs in the left eyebrow were sparse. There was no thickening of the nerves. Routine blood and urine tests were within normal limits. Histopathology confirmed the clinical diagnosis of borderline tuberbuloid (BT) leprosy. No acid-fast bacilli (AFB) were demonstrable. The Mitsuda reaction (with $0 \cdot 1 \mathrm{ml}$ of armadillo-derived lepromin given intradermally) was positive and read $8 \mathrm{~mm}$ in diameter. The patient was put on paucibacillary multidrug therapy (PBMDT) as recommended by the $\mathrm{WHO}^{1}{ }^{1}$ rifampicin $600 \mathrm{mg} / \mathrm{month}$ supervised and dapsone $100 \mathrm{mg} / \mathrm{day}$. After 3 months of therapy the lesion became oedematous, angry looking and slightly tender. Nerves were uninvolved as before and there were no constitutional symptoms. A clinical diagnosis of Type 1 upgrading reaction was made and supported by histopathological examination. Lymphocyte transformation test (LTT) to sonicated Mycobacterium leprae indicated a stimulation index (SI) of 1.8 ( $>2$ being significant).

In view of the location of the lesion and restriction of left upper eyelid movement, oral prednisolone $40 \mathrm{mg}$ /day was given, later increased to $60 \mathrm{mg} /$ day and continued for 12 weeks. There was no appreciable change except that oedema was slightly less and scaling had appeared indicating that the reaction had become subacute (Figure 1). To avoid the serious side-effects of steroid therapy the dose was tapered to $20 \mathrm{mg} / \mathrm{day}$ and stopped after 4 months as there was no further change in the lesion. Following stoppage of steriods injections of sodium antimony gluconate $500 \mathrm{mg}$ im daily were given in addition to PBMDT. After 8 weeks the injections were stopped as there was no significant improvement. At present, even after 18 months' treatment the patient has not come out of reaction but she has not worsened. Histopathology repeated now revealed oedema in the dermal granuloma and heavy lymphocytic infiltration in the periphery of the granuloma suggestive of upgrading reaction (Figure 2).

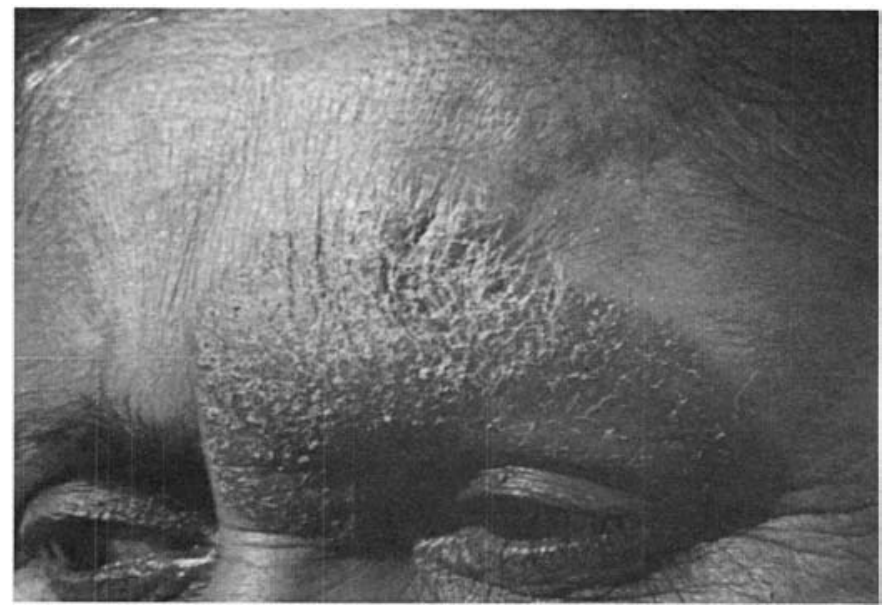

Figure 1. Erythematous scaly plaque on forehead. 


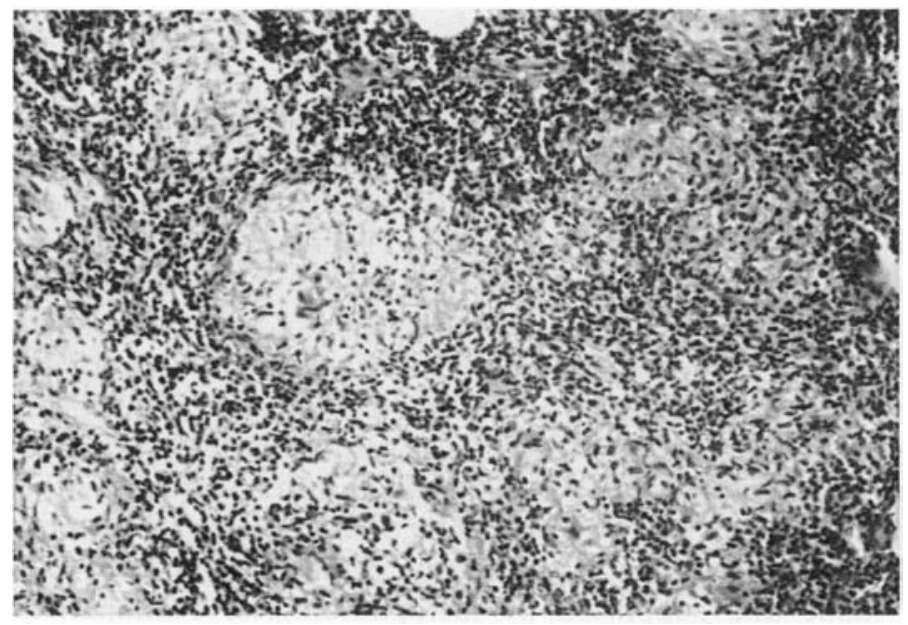

Figure 2. Dermal granuloma showing oedema and dense lymphocytic infiltrate $(\mathrm{HE} \times 400)$.

\section{Case 2}

A 27-year-old woman who sought advice for a patch on the cheek of 8 months' duration was found to have a localized, raised, scaly, indurated red plaque with diminished sensations on the right cheek, $5 \mathrm{~cm}$ in diameter (Figure 3). Local and regional cutaneous nerves were not thickened. Histopathology showed features of BT leprosy with no AFB and the lepromin test read $8 \mathrm{~mm}$. She was advised PBMDT. After $2 \frac{1}{2}$ months the skin lesion started showing signs of reaction with increase in redness and swelling: a diagnosis of Type 1 upgrading reaction was made and confirmed on histopathology. LTT showed an SI of 1.8. Seeing no satisfactory response to nonsteroidal anti-inflammatory drugs, prednisolone was started as for Case 1 and given for a total of 7 months, but still the reaction did not show signs of regression and has persisted for the past 18 months. Histopathology repeated at this stage showed signs of upgrading reaction.

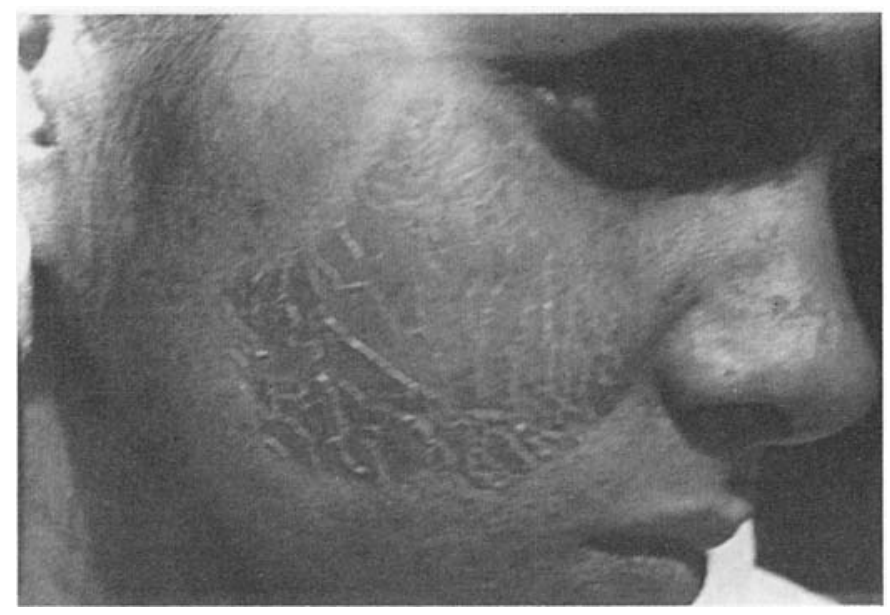

Figure 3. Raised and red scaly plaque on right cheek. 


\section{Case 3}

An 18-year-old boy attended the clinic with a patch on the left cheek of 5 months' duration. Examination revealed an erythematous, indurated, hypoaesthetic plaque $6 \mathrm{~cm}$ in diameter occupying the centre of the left cheek. Nerves in the vicinity of the patch were not affected. Our clinical impression of leprosy was confirmed histopathologically which showed features of BT. Lepromin read $5 \mathrm{~mm}$. He was given PBMDT. After 2 months the lesion showed increasing redness, oedema and slight tenderness. There were signs of leftsided facial palsy and no constitutional symptoms. The patient was immediately put on prednisolone $60 \mathrm{mg} /$ day and aspirin $300 \mathrm{mg}$ three times a day. Within 3 months, during which the steroids were monitored and brought to $20 \mathrm{mg} / \mathrm{day}$, the facial palsy improved appreciably but only tenderness subsided in the skin lesion; the erythema and oedema persisted. Histopathology revealed features of an upgrading reaction and no AFB. Steroids were gradually tapered and stopped after 2 more months of therapy. After 18 months the lesion started regressing and 2 months later it had subsided completely leaving a significant depression in the left cheek and mild-facial palsy (Figure 4). Antileprosy drugs were stopped and the patient was kept under surveillance.

\section{Discussion}

The majority of upgrading or reversal reactions usually occur within the first 6 months of therapy ${ }^{2}$ and seldom continue for more than a few months, ${ }^{3}$ the mean duration recorded in one study being 7.9 weeks. ${ }^{4}$ All 3 patients described in this report were unusual in the sense that the reactions persisted for a long period in the absence of provocative factors like intercurrent infection, pregnancy and obvious mental or physical stress. They were regular in taking therapy and the diagnosis of upgrading reaction was confirmed on histopathology. Slit-skin smears had revealed no AFB.

The first 2 patients with skin involvement did not respond favourably to the drugs given to control the reaction including steroids and injections of sodium antimony

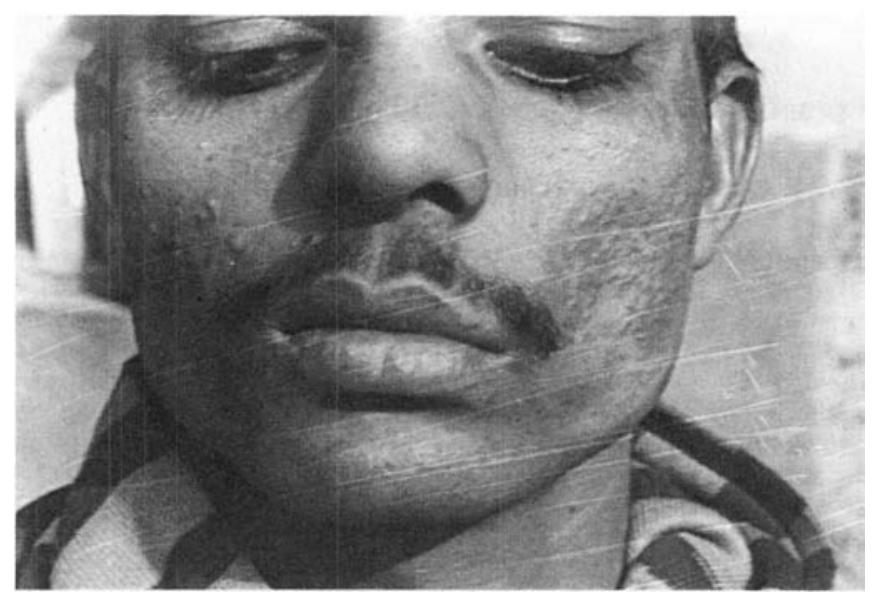

Figure 4. Atrophy of left cheek and mild facial palsy after subsidence of reaction. 
gluconate in 1. Interestingly none of them worsened during the period of observation. The third patient who had both skin and nerve involvement ran a similar course. Here the neuritic component responded relatively earlier and better than the skin lesion, and the facial palsy had improved considerably with therapy. After 18 months the skin lesion subsided unlike the first 2 patients in whom the reaction persisted. This differential response of the skin and nerve may be incidental or may reflect the difference in antigenicity ${ }^{5}$ where the cytoplasmic antigen of $M$. leprae is said to play a predominant role in reactions occurring in nerves and the whole cell antigen in the skin. The significant atrophy seen in the last patient after subsidence of the skin lesion indicates the considerable tissue damage caused when the reaction smoulders for a long time.

LTT done in 2 patients was not significantly raised. This too was unusual as LTT is supposed to be increased in reactional states. ${ }^{6}$ Although no explanation for this can be given at present it may represent an immunological observation in reactions that persist for a long time and can be confirmed when more patients with similar presentations are studied. The absence of constitutional symptoms and no rise in LTT also indicate that local factors may be playing a significant role in such reactions.

\title{
References
}

1 WHO Expert Committee on Leprosy. Technical Report Series 768, 1988.

2 Jopling HW. Handbook of Leprosy. Oxford: William Heinemann, 1984, pp 68-77.

3 Thangaraj HR, Yawalkar JS. Leprosy for Medical Practitioners and Paramedical Workers Basle: Ciba-Geigy, 1988, pp 75-82.

4 Sehgal VN, Rege VL, Mascarenhas MF. Pattern of reactions in leprosy. Lepr India, 1977; 49: 221-8.

5 Barnetson RStc, Bjune G, Pearson JMH, Kronwall G. Cell mediated and humoral immunity in reversal reactions. Int J Lepr 1976; 44: 267-74.

${ }^{6}$ Bjune G, Barnetson RStc, Ridley DS, Kronwall G. LTT in leprosy. Correlation of response with inflammation of the lesion. Clin exp Imm, 1976; 25: 85-94.

\section{Persistance de réaction chez la lèpre paucibacillaire}

\author{
Uma Saxena, V Ramesh, R S Misra et Ashok Mukherjee
}

Sommaire Trois patients avec cas limites de lèpre confirmés par histopathologie, sans évidence de bacilles acido-résistants et avec lésions limitées au visage (deux sur le jumeau, une sur le front), ont été mis sous un traitement à drogues multiples suivant les récommendations de la OMS pour des cas paucibacillaires. Dans une période de trois mois, les lésions ont montré signes de 'réaction augmentée' (ou renversée) corroborés par des résultats d'histopathologie. Chez un des patients, le nerf facial a été affecté, produisant une paralyse facial. L'essai de transformation des lymphocytes n'a pas subi une hausse importante. Tous les trois patients ont pris de la prednisolone par voie orale, mais la réponse n'a pas été bonne, sauf dans un cas, ou la paralyse facial a bien réagi. Des piqûres de gluconat de sodium et d'antimoine administrées chez un patient après avoir arreté des stéroides n'ont pas réussi à controler la réaction. Après 18 mois sous observation régulière pendant le traitement, la réaction cutanée chez le patient avec problèmes du nerf facial a diminué, et a laissé un niveau d'atrophie considérable. Neanmoins, chez les autres deux patients, la lésion cutanée a persisté, avec évidence clinique et d'histopathologie de réaction renversée. Les raisons pour cette persistance anormal de réaction chez ces patients ne sont pas évidentes. 


\title{
Persistencia de reacción inversa en casos de lepra paucibacilar
}

\author{
Uma Saxena, V Ramesh, R S Misra y Ashok Mukherjee
}

Resumen Fueron sometidos a un tratamiento de drogas múltiples tres pacientes con casos inciertos de lepra tuberculosa confirmados histopatológicamente, carentes de bacilos acidorresistentes, y con lesiones limitadas a la cara (dos en la mejilla, una en la frente), según las recommendaciones de la OMS para casos paucibacilares. En un periodo de tres meses, las lesiones mostraron señales de 'réacción aumentada' (o inversa), que fueron corroboradas por resultados histopatológicos. En uno de los pacientes se vió afectado el nervio facial, produciendo una parálisis facial. La prueba de transformación de linfocitos no aumentó de manera importante. Se administró prednisolona por vía oral a los tres pacientes durante periodos entre cinco y siete meses, pero no respondieron bien, excepto en un caso, en el cual la parálisis facial sí respondió de manera favorable. En un paciente, inyecciones de gluconato de sodio y antimonio administradas tras un cese de esteroides, no lograron controlar la reacción. Tras 18 meses bajo observación regular durante el tratamiento, la reacción cutánea en el paciente con problemas de nervio facial disminuyó, dejando un nivel de atrofía considerable. Pero en los otros dos casos persistitió la lesión cutánea, con indícios clínicos e histopatológicos de reacción inversa. Las razones de esta persistencia anormal de reacción no están claras. 